\title{
Metal-free oxidative coupling of thiols to disulfides using guanidinium nitrate or nitro urea in the presence of silica sulfuric acid
}

\author{
ARASH GHORBANI-CHOGHAMARANI*, MOHSEN NIKOORAZM, \\ HAMID GOUDARZIAFSHAR, ALIREZA SHOKR and HOSEIN ALMASI \\ Department of Chemistry, Faculty of Science, Ilam University, P.O. Box 69315516, Ilam, Iran \\ e-mail: arashghch58@yahoo.com
}

MS received 8 April 2010; revised 9 January 2011; accepted 28 February 2011

\begin{abstract}
Efficient combination of nitro urea or guanidinium nitrate and silica sulfuric acid $\left(\mathrm{SiO}_{2} \mathrm{OSO}_{3} \mathrm{H}\right)$ as a new oxidizing system is able to oxidize a variety of aliphatic or aromatic thiols to the corresponding disulfides. The process reported here is operationally simple, environmentally benign and reactions have been mildly and heterogeneously performed in dichloromethane at room temperature.
\end{abstract}

Keywords. Thiols; disulfides; guanidinium nitrate; nitro urea; silica sulfuric acid; oxidation; coupling.

\section{Introduction}

The controlled oxidative coupling of thiols to disulfides is important in organic synthesis. ${ }^{1}$ The conversion of thiols to the corresponding disulfides is an important reaction in chemical and biological process such as vulcanization, ${ }^{2}$ synthesis of $4 \mathrm{H}-1,4$-benzothiazines, ${ }^{3}$ carbon-carbon bond forming, ${ }^{4}$ protein thiol oxidation in tumor cells, ${ }^{5}$ and cysteinyl thiol oxidation in vascular smooth muscle cells. ${ }^{6}$ Oxidation of thiols is the most exploited method for disulfide synthesis mainly because a large number of thiols are commercially available and are easily synthesized. ${ }^{7}$ Thiols and disulfides are important in living cells being a structural feature of many biomolecules including proteins. In many biochemical redox reactions they are interconverted. ${ }^{8}$ In recent years, several reagents or reagent systems have presented ability of thiols coupling into disulfides such as molybdate sulfuric acid/sodium nitrite, ${ }^{9}$ monochloro poly(styrenehydantoin), ${ }^{10}$ tetramethylammonium fluorochromate, ${ }^{11} \mathrm{O}_{2} /$ manganese(III) Schiff-base complex, ${ }^{12} \quad \mathrm{I}_{2} / \mathrm{CeCl}_{3} .7 \mathrm{H}_{2} \mathrm{O} /$ graphite, ${ }^{13}$ ethylenebis ( $N$-methylimidazolium) chlorochromate, ${ }^{14}$ tripropylammonium fluorochromate, ${ }^{15} \mathrm{~N}$-tert-Butyl$N$-chlorocyanamide, ${ }^{16}$ and iron(III) trifluoroacetate/air; ${ }^{17}$ but some of these procedures are not satisfactory because of several reasons such as overoxidation to sulfoxides and other by-products, tedious

*For correspondence work-up of products, low yields, heavy metal contamination, toxicity, and cost effective reagents or catalysts.

\section{Experimental}

The chemicals and solvents were purchased from Fluka, Merck and Aldrich chemical companies and used without further purifications. All products are known and were characterized by comparison of their spectral (IR, ${ }^{1} \mathrm{H}$ NMR, or ${ }^{13} \mathrm{C}$ NMR) and physical data with authentic samples.

\subsection{Preparation of nitro urea $\left(\mathrm{NH}_{2} \mathrm{CONHNO}_{2} \cdot x \mathrm{H}_{2} \mathrm{O}\right)$}

In a $50 \mathrm{~mL}$ round-bottomed flask, $4 \mathrm{~mL}$ of $\mathrm{HNO}_{3}$ $(65 \%)$ and $3.46 \mathrm{~g}$ of urea was stirred at room temperature for $2 \mathrm{~h}$, and a white crystalline solid $\left(\mathrm{NH}_{2} \mathrm{CONHNO}_{2} \cdot \mathrm{xH}_{2} \mathrm{O}\right)$ was obtained quantitatively.

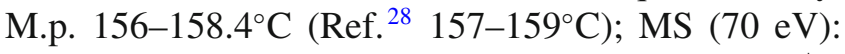
$m / z=105(\mathrm{M}+), 91,69,63,60,46$ (base peak, $\mathrm{NO}_{2}^{+}$), 44.

2.1a Oxidative coupling of 2-mercaptobenzothiazole into 1,2-bis(benzo[d]thiazol-2-yl) disulfane by nitro urea and silica sulfuric acid: As a typical procedure: Nitro urea $\left(\mathrm{NH}_{2} \mathrm{CONHNO}_{2} \cdot \mathrm{xH}_{2} \mathrm{O}\right),(0.40 \mathrm{~g})$ and silica sulfuric acid $(0.60 \mathrm{~g})$ was added to a solution of 2-mercaptobenzoxazole $(0.167 \mathrm{~g}, 1 \mathrm{mmol})$ in $\mathrm{CH}_{2} \mathrm{Cl}_{2}$ 
Table 1. Oxidative coupling of thiols to the corresponding disulfides using combination of guanidinium nitrate I or nitro urea II in the presence of silica sulfuric acid III in dichloromethane at room temperature.

\begin{tabular}{|c|c|c|c|c|c|c|c|c|c|c|}
\hline \multirow[t]{2}{*}{ Entry } & \multirow[t]{2}{*}{ Substrate } & \multirow[t]{2}{*}{ Product } & \multicolumn{3}{|c|}{ Substrate/Reagents $(\mathrm{mmol})^{\mathrm{a}}$} & \multirow{2}{*}{$\begin{array}{l}\text { Time } \\
\text { (Min) }\end{array}$} & \multirow{2}{*}{$\begin{array}{l}\text { Yield } \\
(\%)^{\mathrm{b}}\end{array}$} & \multirow{2}{*}{$\begin{array}{l}\mathrm{Mp}\left({ }^{\circ} \mathrm{C}\right) \\
\text { found }\end{array}$} & \multirow{2}{*}{$\begin{array}{l}\mathrm{Mp}\left({ }^{\circ} \mathrm{C}\right) \\
\text { reported }\end{array}$} & \multirow[t]{2}{*}{ Reference } \\
\hline & & & I & II & III & & & & & \\
\hline 1 & $\mathbf{1 a}$ & $2 \mathbf{a}$ & 2.5 & - & 0.6 & 20 & 86 & $138-139$ & $144-146$ & (9) \\
\hline 2 & $1 \mathbf{a}$ & $\mathbf{2 a}$ & - & 0.4 & 0.6 & 15 & 88 & $139-141$ & & \\
\hline 3 & $\mathbf{1 b}$ & $2 \mathbf{b}$ & 2.5 & - & 0.6 & 17 & 90 & 89-91 & $90-92$ & (9) \\
\hline 4 & $1 \mathbf{b}$ & $\mathbf{2 b}$ & - & 0.4 & 0.6 & 40 & 87 & $89-91$ & & \\
\hline 5 & 1c & $2 c$ & 2.5 & - & 0.6 & 10 & 88 & oil & oil & $(27)$ \\
\hline 6 & 1c & $2 c$ & - & 0.4 & 0.6 & 22 & 84 & oil & & \\
\hline 7 & 1d & $2 d$ & 2.5 & - & 0.6 & 8 & 92 & $41-41.5$ & $43-44$ & (9) \\
\hline 8 & 1d & $2 d$ & - & 0.4 & 0.6 & 15 & 92 & $39-41$ & & \\
\hline 9 & $1 e$ & $2 e$ & 2.5 & - & 0.6 & 17 & $92^{\mathrm{d}}$ & $43-44$ & $42-43$ & (13) \\
\hline 10 & $1 e$ & $2 e$ & - & 0.4 & 0.6 & 28 & $95^{\mathrm{d}}$ & $41-43$ & & \\
\hline 11 & 1f & $2 f$ & 2.5 & - & 0.6 & 10 & 95 & $283-285$ & $278-280$ & (24) \\
\hline 12 & 1f & $2 f$ & - & 0.4 & 0.6 & 26 & 93 & $283-286$ & & \\
\hline 13 & $1 \mathrm{~g}$ & $2 \mathrm{~g}$ & 2.5 & - & 0.6 & 22 & 96 & 89-91 & $78-92$ & (27) \\
\hline 14 & $1 \mathrm{~g}$ & $2 \mathrm{~g}$ & - & 0.4 & 0.6 & 51 & 97 & $77-84$ & & \\
\hline 15 & $1 \mathrm{~h}$ & $2 h$ & 2.5 & - & 0.6 & 10 & 90 & $77.6-79$ & $77.5-79$ & (24) \\
\hline 16 & 1h & $2 h$ & - & 0.4 & 0.6 & 7 & 96 & $75-78$ & & \\
\hline 17 & $1 \mathrm{~h}$ & $2 \mathrm{~h}$ & 2.5 & - & - & $5 \mathrm{~h}$ & No Reac. & - & - & - \\
\hline 18 & 1h & $2 \mathrm{~h}$ & - & 0.4 & - & $5 \mathrm{~h}$ & No Reac. & - & & \\
\hline 19 & $1 \mathbf{i}$ & $2 \mathrm{i}$ & 2.5 & - & 0.6 & 19 & 86 & $177.5-178$ & $177-179$ & (9) \\
\hline 20 & $\mathbf{1 i}$ & $2 \mathrm{i}$ & - & 0.4 & 0.6 & 10 & 80 & $177-179$ & & \\
\hline 21 & $1 \mathbf{j}$ & $2 \mathbf{j}$ & 2.5 & - & 0.6 & 39 & 92 & $68-70$ & $70-71$ & (8) \\
\hline 22 & $\mathbf{1 j}$ & $2 \mathrm{j}$ & - & 0.4 & 0.6 & 78 & 88 & $68-70$ & & \\
\hline 23 & $1 \mathrm{k}$ & $2 \mathbf{k}$ & 2.5 & - & 0.6 & 21 & 91 & $166.5-168$ & $167-169$ & (13) \\
\hline 24 & $1 k$ & $2 \mathbf{k}$ & - & 0.4 & 0.6 & 40 & 92 & $165-167$ & & \\
\hline 25 & 11 & 21 & 2.5 & - & 0.6 & 22 & 62 & oil & oil & (24) \\
\hline 26 & 11 & 21 & - & 0.4 & 0.6 & 16 & 61 & oil & & \\
\hline 27 & $1 \mathrm{~m}$ & $2 \mathrm{~m}$ & 2.5 & - & 0.6 & 12 & 63 & oil & oil & (8) \\
\hline 28 & $1 \mathrm{~m}$ & $2 \mathrm{~m}$ & - & 0.4 & 0.6 & 52 & 64 & oil & & \\
\hline
\end{tabular}


${ }^{b}$ Isolated yield. ${ }^{c}$ In the absence of silica sulfuric acid. ${ }^{\mathrm{d}}$ Product purified by column chromatography

$(10 \mathrm{~mL})$. The resulting mixture was stirred at room temperature for $10 \mathrm{~min}$ (the reaction progress was monitored by TLC) and then filtered. The residue was washed with $\mathrm{CH}_{2} \mathrm{Cl}_{2}(4 \times 5 \mathrm{~mL})$. Finally, $\mathrm{CH}_{2} \mathrm{Cl}_{2}$ was removed and 1,2-bis(2-benzoxazol)disulfane was obtained in $80 \%$ yield $(0.258 \mathrm{~g})$ as crystalline white solid; mp 177-179 ${ }^{\circ} \mathrm{C}$; H NMR (400 MHz, $\left.\mathrm{CDCl}_{3}\right): \delta=$ 7.96-7.94 (d, J = 8 Hz, 1H), 7.80-7.78 (d, J = 8 Hz, $1 \mathrm{H}), 7.50-7.46(\mathrm{t}, \mathrm{J}=7.6 \mathrm{~Hz}, 1 \mathrm{H}), 7.39-7.35(\mathrm{t}, \mathrm{J}=$ $7.2 \mathrm{~Hz}, 1 \mathrm{H}) \mathrm{ppm} ;{ }^{13} \mathrm{C}$ NMR $\left(100 \mathrm{MHz}, \mathrm{CDCl}_{3}\right): \delta=$ $167.9,154.6,136.2,126.6,125.3,122.7,121.3$ ppm. All the thiols converted into disulfides via same procedure except compounds $\mathbf{f}, \mathbf{l}$ and $\mathbf{m}$.

$2.1 \mathrm{~b}$ General procedure for the oxidative coupling of thiols $\mathbf{1 f}, \mathbf{1 1}$ and $\mathbf{1 m}$ into disulfides $\mathbf{2 f}, \mathbf{2 l}$ and $\mathbf{2 m}$ using guanidinium nitrate or nitro urea in the presence of silica sulfuric acid: To a mixture of guanidinium nitrate or nitro urea, (2.5 mmol or $0.4 \mathrm{~g}$, respectively) and silica sulfuric acid $(0.6 \mathrm{~g})$ in $\mathrm{CH}_{2} \mathrm{Cl}_{2}(10 \mathrm{~mL})$ one of the thiols 1f, 11 or $\mathbf{1 m}(1 \mathrm{mmol})$ was added, and the mixture was stirred at room temperature for the specified time (table 1) the reaction progress was monitored by TLC. After reaction completion $\mathrm{CH}_{2} \mathrm{Cl}_{2}$ was evaporated and ethanol $(10 \mathrm{~mL})$ was added to the residue, this mixture was stirred for 5 minutes then filtered. The residue was washed with $\mathrm{CH}_{3} \mathrm{CH}_{2} \mathrm{OH}(4 \times 5 \mathrm{~mL})$.<smiles>NC(=O)N[N+](=O)[O-]</smiles>

Figure 1. Chemical structures of guanidinium nitrate and nitro urea. 


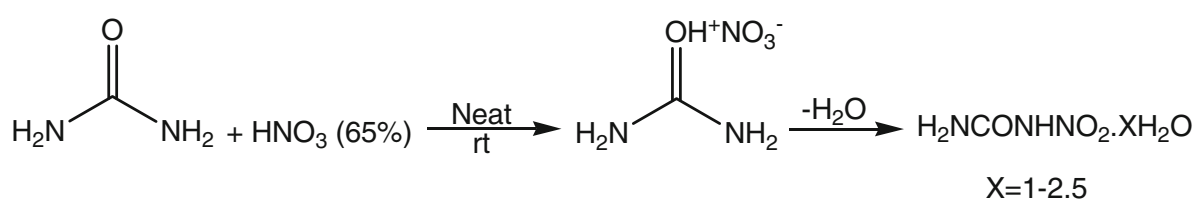

Scheme 1. Preparation of nitro urea.

Finally, $\mathrm{CH}_{3} \mathrm{CH}_{2} \mathrm{OH}$ was removed by rotary evaporator and resulting sediment was washed with $\mathrm{H}_{2} \mathrm{O}(4 \times$ $20 \mathrm{~mL}$ ) and dried under vacuum to give pure disulfides 2f, $2 \mathbf{l}$ or $\mathbf{2 m}$.

\subsection{Representative NMR Data}

2.2a 1,2-Bis(4-bromophenyl)disulfane $2 b:{ }^{1} \mathrm{H}$ NMR $\left(500 \mathrm{MHz}, \mathrm{CDCl}_{3}\right): \delta=7.43(\mathrm{~d}, \mathrm{~J}=8.4 \mathrm{~Hz}, 4 \mathrm{H}), 7.36$ $(\mathrm{d}, \mathrm{J}=7.9 \mathrm{~Hz}, 4 \mathrm{H}) \mathrm{ppm} ;{ }^{13} \mathrm{C} \mathrm{NMR}\left(125 \mathrm{MHz}, \mathrm{CDCl}_{3}\right)$ : $\delta=135.8,132.3,129.5,121.6 \mathrm{ppm}$.

2.2b 1,2-Dip-tolyldisulfane 2d: ${ }^{1} \mathrm{H}$ NMR (500 MHz, $\left.\mathrm{CDCl}_{3}\right): \delta=7.42(\mathrm{~d}, \mathrm{~J}=7.9 \mathrm{~Hz}, 4 \mathrm{H}), 7.42(\mathrm{~d}, \mathrm{~J}=$ $7.9 \mathrm{~Hz}, 4 \mathrm{H}), 2.35$ (s, 6H) ppm; ${ }^{13} \mathrm{C} \mathrm{NMR}(125 \mathrm{MHz}$, $\left.\mathrm{CDCl}_{3}\right): \delta=137.5,134.0,129.8,128.6,21.1 \mathrm{ppm}$.

\section{2c 1,2-Bis((4,6-dimethylpyrimidin-2-}

yl)methyl)disulfane $2 \mathrm{k}:{ }^{1} \mathrm{H} \mathrm{NMR}\left(500 \mathrm{MHz}, \mathrm{CDCl}_{3}\right)$ : $\delta=6.76(\mathrm{~s}, 2 \mathrm{H}), 2.39(\mathrm{~s}, 12 \mathrm{H}) \mathrm{ppm} ;{ }^{13} \mathrm{C} \mathrm{NMR}$ $\left(125 \mathrm{MHz}, \mathrm{CDCl}_{3}\right): \delta=169.0,167.6,117.1,23.8 \mathrm{ppm}$.

\section{Results and discussion}

Recently we have introduced several heterogeneous procedures for the in situ generation of nitronium ion $\left(\mathrm{NO}_{2}^{+}\right)$and nitrosonium ion $\left(\mathrm{NO}^{+}\right)$for different organic functional group transformations. ${ }^{18-26}$ In continuation of our investigation we became interested to delineate a new protocol to convert different types of thiols to the corresponding disulfides by guanidinium nitrate or nitro urea (figure 1) in the presence of silica sulfuric acid.

Guanidinium nitrate as commercially available reagent is a natural source of nitronium ion. While nitro urea could be easily prepared by the reaction of urea with nitric acid to produce urea nitrate, which immediately dehydrated to nitro urea (scheme 1). ${ }^{27,28}$

Consequently, we decided to use guanidinium nitrate and nitro urea in the presence of silica sulfuric acid for the oxidative coupling of aliphatic and aromatic thiols to prepare corresponding disulfide derivatives. Therefore, a variety of aliphatic and aromatic thiols $\mathbf{1}$ converted into corresponding disulfides 2 by combination of guanidinium nitrate I or nitro urea II and silica sulfuric acid III in dichloromethane as solvent at room temperature (scheme 2 and table 1).

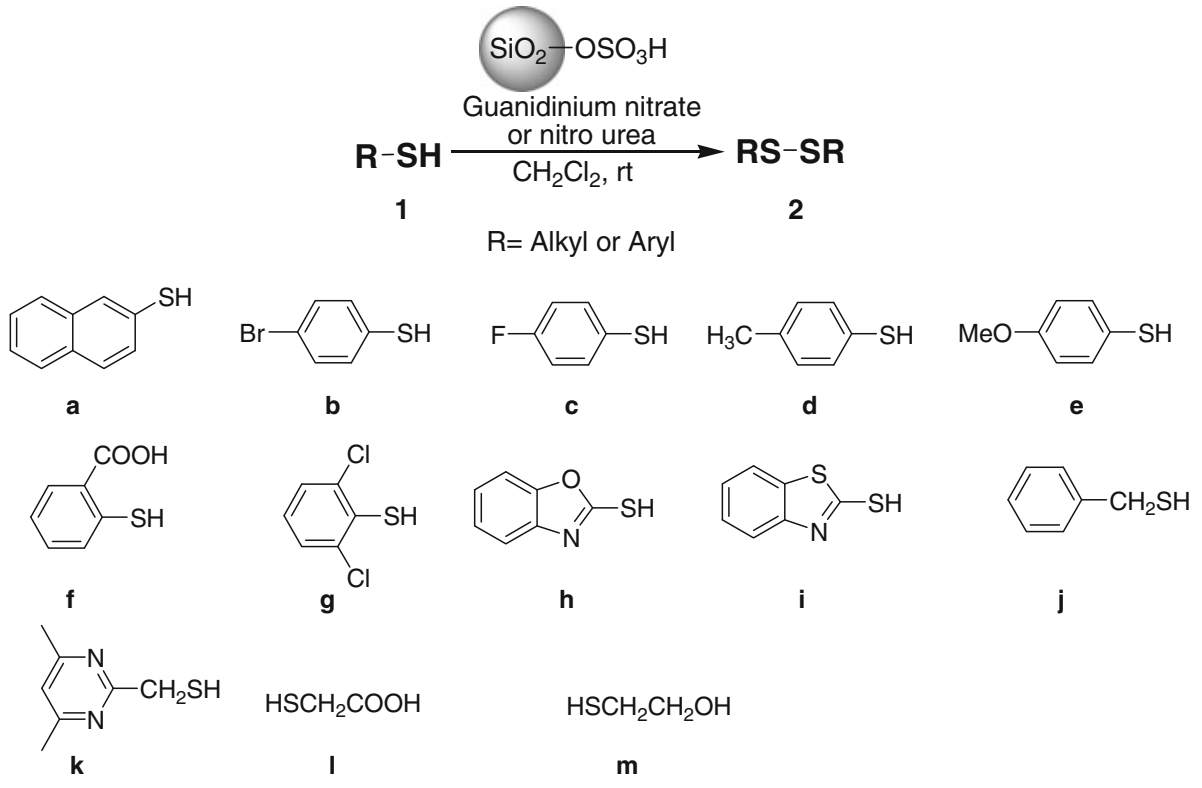

Scheme 2. Oxidative coupling of thiols by guanidinium nitrate or nitro urea in the presence of silica sulfuric acid. 


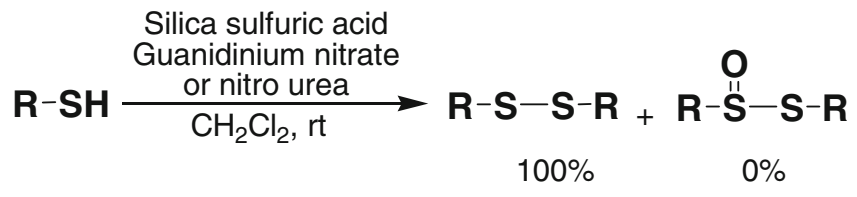

Scheme 3. Chemoselectivity in the oxidative coupling of thiols.

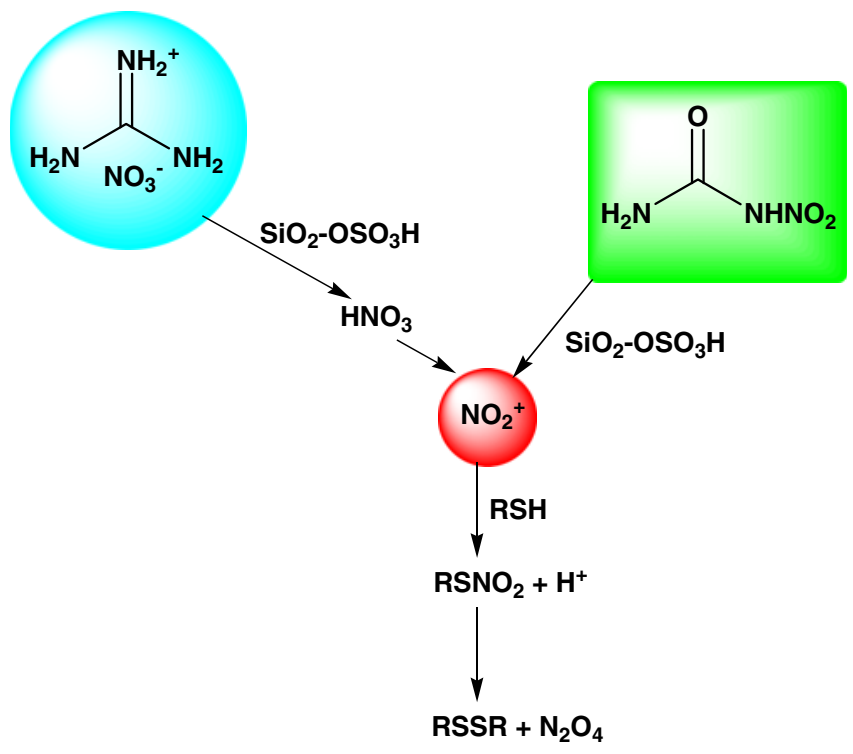

Scheme 4. Mechanism of oxidative coupling of thiols.

All the coupling reactions were performed easily by mixing of a thiol, guanidinium nitrate or nitro urea and silica sulfuric acid in dichloromethane and stirring this mixture for appropriate time at room temperature. Finally, pure product readily obtained by simple filtration, washing by appropriate solvent $\left(\mathrm{CH}_{2} \mathrm{Cl}_{2}\right.$ or $\mathrm{CH}_{3} \mathrm{CH}_{2} \mathrm{OH}$ ) and evaporation of the solvent. Because of mild properties of these heterogeneous systems, there is no overoxidation to sulfone was observed (scheme 3 ).

Silica sulfuric acid has a critical role in the coupling reaction by described reagents. Entries 17 and 18 from table 1 show that the coupling of 2-mercaptobenzoxazole into 1,2-bis(2benzoxazol)disulfane using guanidinium nitrate and nitro urea, as a standard reaction, in the absence of silica sulfuric acid does not occur after $5 \mathrm{~h}$.

A suggested mechanism of this oxidation is outlined in scheme 4 based on our previously reported works, ${ }^{19,21,22,24}$ our observations and obtained results.

\section{Conclusion}

In summary, in this investigation an effective and new oxidizing media has been introduced for the preparation of disulfides under mild, metal-free and heterogeneous conditions. Furthermore, this method exhibits substrate versatility, non-toxic conditions, cost effective reagents, easy and clean work-up of products.

\section{Acknowledgements}

This work was supported by the research facilities of Ilam University, Ilam, Iran.

\section{References}

1. Kirihara M, Asai Y, Ogawa S, Noguchi T, Hatano A and Hirai Y 2007 Synthesis 3286

2. Ramadas K and Srinivasan 1995 Synthetic Commun. 25 227

3. Srivastav V, Gupta R and Guptam RR 2000 Indian J. Chem. 39B 223

4. Metzner P 1992 Synthesis 1185

5. Seoa Y H and Carroll K S 2009 Natl. P. Acad. Sci. USA 3816163

6. Maron B A, Zhang Y Y, Handy D E, Beuve A, Tang S S, Loscalzo J and Leopold J A 2009 J. Biol. Chem. 284 7665

7. Alam A, Takaguchi Y and Tsuboi S 2005 Synthetic Commun. 351329 
8. Ozen1 R and Aydin F 2006 Monatsh. Chem. 137 307

9. Montazerozohori M, Karami B and Azizi M 2007 Arkivoc 99

10. Akdag A, Webb T and Worley S D 2006 Tetrahedron Lett. 473509

11. Imanieh H, Ghamami S, Mohammadi M K and Jangjoo A 2007 Russ. J. Gen. Chem. 77282

12. Golchoubian H and Hosseinpoor F 2007 Catal. Commun. 8697

13. Silveira C C and Mendes S R 2007 Tetrahedron Lett. 48 7469

14. Hosseinzadeh R, Tajbakhsh M, Khaledi $\mathrm{H}$ and Ghodrati K 2007 Monatsh. Chem. 138871

15. Hassani-Joshaghani A, Ghammamy S, Bagi S, Moghimi A and Javanshir Z 2009 Phosphorus Sulfur and Silicon 184164

16. Kumar V and Kaushik M P 2008 Bull. Chem. Soc. Japan 81160

17. Adibi H, Samimi H A and Iranpoor N 2008 Chin. J. Chem. 262086

18. Ghorbani-Choghamarani A, Goudarziafshar H, Nikoorazm M and Yousefi S 2009 Lett. Org. Chem. 6 535
19. Ghorbani-Choghamarani A and Rezaei S 2009 J. Chin. Chem. Soc. 56251

20. Ghorbani-Choghamarani A, Goudarziafshar H, Nikoorazm M and Yousefi S 2009 Can. J. Chem. 87 1144

21. Ghorbani-Choghamarani A, Hajjami M, Goudarziafshar H, Nikoorazm M, Mallakpour S, Sadeghizadeh F and Azadi G 2009 Monatsh. Chem. 140607

22. Ghorbani-Choghamarani A, Zolfigol M A and Rastegar T 2009 Chin. J. Catal. 30273

23. Goudarziafshar H, Ghorbani-Choghamarani A, Nikoorazm M and Naserifar Z 2009 Chin. J. Chem. 27 1801

24. Ghorbani-Choghamarani A, Nikoorazm M, Goudarziafshar H and Tahmasbi B 2009 Bull. Korean Chem. Soc. 301388

25. Ghorbani-Choghamarani A, Nikoorazm M, Goudarziafshar H, Shiri L and Chenani Z 2009 Bull. Korean Chem. Soc. 30972

26. Ghorbani-Choghamarani A, Goudarziafshar H, Rezaee S and Mortazavi S S 2009 Chin. Chem. Lett. 20415

27. Shead A C 1967 Mikrochim. Acta. 593

28. Almog J, Klein A, Sokol A, Sasson Y, Sonenfeld D and Tamiri T 2006 Tetrahedron Lett. 478651 